\title{
PENERAPAN MOBILE VIDEO EFEKTIF MENINGKATKAN PENGETAHUAN DAN SIKAP IBU DALAM MENURUNKAN LAMA DIARE BALITA DI WILAYAH PUSKESMAS KEDATON BANDAR LAMPUNG
}

\author{
Yuli Lestari ${ }^{1, *}$, Nani Nurhaeni ${ }^{2}$, Happy Hayati ${ }^{2}$ \\ 1. STIKes Mitra Lampung, Lampung 35132, Indonesia \\ 2. Fakultas Ilmu Keperawatan Universitas Indonesia, Depok 16424, Indonesia \\ *E-mail: yulilestari.mitra@gmail.com
}

\begin{abstract}
Abstrak
Penanganan diare yang tepat dan edukasi manajemen diare pada ibu dapat menurunkan angka kesakitan dan kematian balita karena diare. Penelitian ini bertujuan untuk menguji efektifitas edukasi video penanganan diare terhadap pengetahuan dan sikap ibu dalam penanganan diare, serta lama diare balita. Desain penelitian menggunakan pre-post test dengan kontrol group. Total sampel sejumlah 71 responden dibagi kelompok intervensi dan kontrol yang dipilih menggunakan teknik consecutive sampling. Hasil penelitian menunjukkan terdapat perbedaan bermakna antara pengetahuan dan sikap sebelum dan sesudah edukasi pada kelompok intervensi (pengetahuan: $p=0,002 ;$ sikap $p=$ 0,008); terdapat perbedaan bermakna antara selisih skor pengetahuan dan sikap antar kelompok (pengetahuan $\mathrm{p}=0,008$; sikap $\mathrm{p}=0,001$ ), namun tidak ada perbedaan yang bermakna antara lama diare kelompok kontrol dengan intervensi ( $\mathrm{p}=$ 0,796). Edukasi video efektif meningkatkan pengetahuan dan sikap, namun tidak pada variabel lama diare. Edukasi melalui audiovisual dapat dipertimbangkan sebagai asuhan keperawatan karena keefektifannya dalam meningkatkan pengetahuan dan sikap ibu menangani anak diare.
\end{abstract}

Kata Kunci: edukasi audiovisual, lama diare, manajemen diare

\section{Abstract}

Application of Mobile Video Effective to Increase the Knowledge and Attitude in Managing Diarrhea of the Mothers and to Reduce Diarrhea Duration of Under Five Children. Proper handling of diarrhea and education of diarrhea management in mothers can decrease morbidity and mortality of children under five due to diarrhea. This study aimed to examine the effectiveness of video education about management of diarrhea toward knowledge and attitude of the mother, and duration diarrhea of under five children. The design applied a pre and post-test with the control group. The total sample was 71 respondents divided to control group and interventions were selected by consecutive sampling technique. The results showed that there were significant differences between knowledge and attitude before and after education in interventions (knowledge: $p=0.002$; attitude $p=0.008$ ). There was a significant difference between score knowledge and attitude control group and interventions (knowledge $p=0.008$; attitude $p=0.001$ ), but there was no significant difference between duration diarrhea control group and interventions $(p=0.796)$. Video education enhanced knowledge and attitude of the mother, but not to the duration of diarrhea. Audiovisual can be considered as a nursing intervention because its effectiveness to increase knowledge and attitude of the mother in handling the children with diarrhea.

Keywords: audiovisual education, attitude, diarrhea management, duration of diarrhea

\section{Pendahuluan}

Diare merupakan penyakit penyebab utama tingginya angka kesakitan dan kematian pada anak di bawah 5 (lima) tahun di negara ber- kembang (WHO, 2009; WHO, 2013; WHO, 2015). Tepatnya $24 \%$ kematian anak di negara berkembang disebabkan karena diare dan dehidrasi (Hockenberry \& Wilson, 2013). Asia Tenggara berada pada urutan ke-2 dengan ang- 
ka kematian anak usia dibawah 5 tahun karena diare. Diare di Indonesia sebesar rata-rata 1,5 per 1000 kelahiran hidup anak usia 1-59 bulan (UNICEF, 2015; WHO, 2015). Di Provinsi Lampung diare berpotensi menjadi Kejadian Luar Biasa (KLB). Kematian bayi (usia 29 hari -11 bulan) yang disebabkan oleh diare sebesar $31,4 \%$ dan pada balita (usia $12-59$ bulan) sebesar 25,2\%. Berdasarkan data tersebut dapat disimpulkan bahwa diare merupakan masalah kesehatan yang perlu diperhatikan karena menjadi penyumbang kematian tertinggi pada balita (Kemenkes RI, 2011; Dinas Kesehatan Provinsi Lampung, 2014).

Penatalaksanaan diare di rumah dengan manajemen yang tepat dapat mengurangi keparahan diare, Namun demikian kasus diare anak juga dapat menyebabkan komplikasi dehidrasi sehingga memerlukan penatalaksanaan di ruang gawat darurat untuk mendapat terapi cairan intravena. Carusso, Stephenson, dan Leon (2011) menyatakan kesehatan anak dengan diare sebagian besar dikendalikan oleh pengalaman ibu. Faktor pendidikan ibu juga menjadi masalah penting dalam penatalaksanaan diare di rumah untuk menurunkan keparahan diare pada anak (Yilgwan, 2012; Becker-Dreps et al., 2014). Yalew (2014) menemukan di wilayah Ethiopia persepsi ibu tentang pemahaman pengasuh dalam perawatan diare sangat penting sebelum anak dibawa ke rumah sakit atau klinik. Peran orang tua dalam perawatan anak akan menjadi optimal bila dibekali dengan pengetahuan dan sikap yang baik (Kanugo, et al., 2014; Lamberti, et al., 2015; Silah, et al., 2013)

Edukasi dapat memberi bekal pengetahuan dan menciptakan sikap positif ibu tentang penyebab, pencegahan, dan manajemen diare (Merga \& Alemayehu, 2015). Edukasi memerlukan persiapan dan perlu kompetensi karena melibatkan transmisi informasi untuk meningkatkan pemahaman seseorang (Hockenberry \& Wilson, 2013). Media yang dianggap baik dalam menyampaikan informasi adalah media audiovisual. Media audiovisual diberikan melalui media digital menggunakan kata-kata yang diucap- kan dalam bentuk ilustrasi, foto, animasi atau video (Clark \& Mayer, 2016). Media ini dapat menyalurkan pengetahuan ke otak lebih maksimal karena memberikan gambaran yang lebih nyata dan dapat meningkatkan retensi memori karena menarik dan mudah diingat dibanding dengan media lain (Maulana, 2009; Sadiman et al., 2009). Media audiovisual juga dianggap mudah dipahami oleh orang dengan pendidikan rendah. Nascimento, et al. (2014) melaporkan bahwa video pendidikan terbukti meningkatkan self-efficacy ibu di Brazil dalam pencegahan dan penatalaksanaan bayi diare.

Media audiovisual dapat diakses melalui komputer, gawai, dan media elektronik lainnya. Pada era digitalisasi saat ini, angka pengguna ponsel pintar di Indonesia kini mencapai sekitar $25 \%$ dari total penduduk atau sekitar 65 juta orang (Menristekdikti, 2017). Kemudahan seseorang memiliki dan tingginya angka penggunaan ponsel pintar memberi peluang besar dalam mengaplikasikan edukasi dengan media video. Tujuan penelitian ini adalah untuk menguji efektifitas edukasi audiovisual perawatan diare terhadap pengetahuan dan sikap ibu, serta lama diare balita di wilayah puskesmas Kedaton Bandar Lampung.

\section{Metode}

Desain penelitian ini menggunakan pre-posttest dengan control group. Penelitian ini dilakukan di Wilayah Puskesmas Kedaton Bandar Lampung selama sebulan. Populasi dalam penelitian ini yaitu ibu dengan balita diare yang datang ke Puskesmas Kedaton. Sampel penelitian yaitu 71 responden dengan kriteria inklusi: (1) Ibu balita (usia 2-59 bulan) dengan diare, (2) Balita diare dengan atau tanpa demam, (3) Ibu merawat balitanya sendiri dirumah, (4) Ibu dapat membaca dan menulis. Kriteria eksklusi yaitu: (1) Balita diare dengan penyakit penyerta lain (seperti: batuk, demam karena infeksi penyakit lain, (2) Ibu sakit, (3) Ibu dengan balita yang perlu dirawat inap karena diare. Teknik pengambilan sampel menggunakan teknik consecutive sampling. 
Alat pengumpul data menggunakan kuesioner dan lembar follow up. Analisis data menggunakan Uji Chi-Square untuk menguji data kategorik tidak berpasangan, uji Mc Nemar untuk menguji data kategorik berpasangan, dan uji Mann Whitney untuk menguji data numerik tidak berpasangan.

Kuesioner terdiri dari 18 item tentang diare dan perawatan diare di rumah untuk mengukur pengetahuan. Skor pengetahuan berdasar jumlah jawaban benar. Pengukuran variabel sikap juga menggunakan kuesioner yang terdiri dari 18 item dalam bentuk pernyataan positif dan negatif menggunakan skala Likert, untuk pernyataan positif diberikan skor dengan ketentuan $1=$ sangat tidak setuju terhadap pernyataan, $2=$ tidak setuju, $3=$ setuju, dan $4=$ sangat setuju. Sebaliknya untuk pemberian skor pada pernyataan negatif. Uji validitas kuesioner pengetahuan didapatkan nilai $\mathrm{r}=0,365-0,817$ dengan Cronbach alpha sebesar 0,876; sikap didapatkan $\mathrm{r}=0,431-0,900$ dengan cronbach alpha sebesar 0,740 . Intervensi yang diberikan adalah edukasi menggunakan media audiovisual. Penelitian yang dilakukan sudah lolos kaji etik dari Universitas Indonesia, dimana kelompok kontrol mendapatkan edukasi audiovisual setelah data selesai diambil.

\section{Hasil}

Hasil penelitian menunjukkan bahwa pengetahuan kurang (skor jawaban responden < 49) pada kelompok intervensi sebelum edukasi adalah 8 orang; sesudah edukasi adalah 1 orang. Hasil uji statistik menunjukkan ada perbedaan yang bermakna antara pengetahuan sebelum dengan sesudah edukasi $(\mathrm{p}=0,002)$. Pengetahuan kurang kelompok kontrol sebelum edukasi adalah 7 orang; sesudah edukasi adalah 5 orang. Hasil uji statistik menunjukkan ada perbedaan yang bermakna antara pengetahuan sebelum dengan sesudah edukasi pada kelompok kontrol $(\mathrm{p}=0,018)$ yang dapat dilihat pada Tabel 1.

Sikap negatif (skor jawaban responden < 75) kelompok intervensi sebelum edukasi adalah 21 orang; sesudah edukasi adalah 13 orang. Hasil uji statistik menunjukkan ada perbedaan yang bermakna antara sikap sebelum dengan sesudah edukasi $(p=0,008)$. Sikap negatif kelompok kontrol sebelum edukasi adalah 13 orang; sesudah edukasi adalah 9 orang. Hasil uji statistik menunjukkan tidak ada perbedaan yang bermakna antara sikap sebelum dengan sesudah edukasi $(\mathrm{p}=0,125)$ yang dapat dilihat pada Tabel 2.

Tabel 1. Perbedaan Pengetahuan Ibu pada Kelompok Intervensi dan Kontrol berdasarkan Pre-test dan PostTest

\begin{tabular}{|c|c|c|c|c|c|}
\hline \multirow{2}{*}{ Variabel } & \multicolumn{3}{|c|}{ Pengetahuan Post Test } & \multirow{2}{*}{ Total } & \multirow[b]{2}{*}{$\mathrm{p}$} \\
\hline & Baik & Cukup & Kurang & & \\
\hline \multicolumn{6}{|l|}{ Kelompok Intervensi } \\
\hline \multicolumn{6}{|l|}{ Pengetahuan Pre Test } \\
\hline a. Baik & 13 & 0 & 0 & 13 & \multirow{4}{*}{0,002} \\
\hline b. Cukup & 8 & 7 & 0 & 15 & \\
\hline c. Kurang & 2 & 5 & 1 & 8 & \\
\hline Total & 23 & 12 & 1 & 36 & \\
\hline \multicolumn{6}{|l|}{ Kelompok Kontrol } \\
\hline Pengetahuan Pre Test & & & & & \multirow{5}{*}{0,018} \\
\hline a. Baik & 11 & 0 & 0 & 11 & \\
\hline b. Cukup & 6 & 11 & 0 & 17 & \\
\hline c. Kurang & 0 & 2 & 5 & 7 & \\
\hline Total & 17 & 13 & 5 & 35 & \\
\hline
\end{tabular}


Tabel 2. Perbedaan Sikap Ibu pada Kelompok Intervensi dan Kontrol berdasarkan Pre-test dan Post-test

\begin{tabular}{|c|c|c|c|c|}
\hline \multirow{2}{*}{ Variabel } & \multicolumn{2}{|c|}{ Sikap Post Test } & \multirow{2}{*}{ Total } & \multirow[b]{2}{*}{$\mathrm{p}$} \\
\hline & Positif & Negatif & & \\
\hline \multicolumn{5}{|l|}{ Kelompok Intervensi } \\
\hline \multicolumn{5}{|l|}{ Sikap Pre Test } \\
\hline a. Positif & 15 & 0 & 15 & 0,008 \\
\hline b. Negatif & 8 & 13 & 21 & \\
\hline Total & 23 & 13 & 36 & \\
\hline \multicolumn{5}{|l|}{ Kelompok Kontrol } \\
\hline a. Positif & 22 & 0 & 22 & 0,125 \\
\hline b. Negatif & 4 & 9 & 13 & \\
\hline Total & 26 & 9 & 35 & \\
\hline
\end{tabular}

Tabel 3. Perbedaan Selisih Skor Pengetahuan dan Sikap Ibu pada Kelompok Intervensi dan Kontrol Berdasarkan Pre-test dan Post-test

\begin{tabular}{llcccc}
\hline \multicolumn{1}{c}{ Variabel } & \multicolumn{1}{c}{ Kelompok } & $\mathrm{n}$ & Mean diff* & Selisih & $\mathrm{p}$ \\
\hline Pengetahuan & Intervensi & 36 & 11,5 & 4,9 & 0,008 \\
\multirow{2}{*}{ Sikap } & Kontrol & 35 & 6,6 & & \\
& Intervensi & 36 & 3,61 & 2,38 & 0,001 \\
\hline
\end{tabular}

Tabel 4. Perbedaan Lama Diare Balita pada Kelompok Intervensi dan Kontrol berdasarkan Pre test dan Post Test

\begin{tabular}{cccccc}
\hline Variabel & Kelompok & $\mathrm{n}$ & $\begin{array}{c}\text { Median } \\
(\text { Min }- \text { Max })\end{array}$ & Rerata \pm SD & $\mathrm{p}$ \\
\hline Lama diare & Intervensi kontrol & 36 & $2(1-4)$ & $2,08 \pm 0,993$ & 0,796 \\
\hline
\end{tabular}

Hasil uji statistik menunjukkan ada perbedaan yang bermakna antara selisih skor pengetahuan kelompok intervensi dengan kelompok kontrol $(\mathrm{p}=0,008)$; ada perbedaan yang bermakna antara selisih skor sikap kelompok intervensi dengan kelompok kontrol $(\mathrm{p}=0,001)$, namun hasil uji statistik menunjukkan tidak ada perbedaan yang bermakna antara lama diare kelompok intervensi dengan kelompok kontrol $(\mathrm{p}=0,796)$ yang dapat dilihat pada Tabel 3 dan Tabel 4.

\section{Pembahasan}

Pengetahuan kurang jika dibandingkan sebelum dan sesudah intervensi pada kelompok in- tervensi mengalami penurunan lebih besar dibandingkan dengan kelompok kontrol. Dapat dilihat pada Tabel 1 bahwa jumlah responden kelompok intervensi dengan pengetahuan kurang menurun sebanyak tujuh responden sedangkan pada kelompok kontrol menurun sebanyak dua responden. Penelitian ini sesuai dengan penelitian Kanungo, et al. (2014) yang menemukan bahwa tingkat pengetahuan tentang penanganan diare paling baik pada kelompok intervensi dibanding dengan kelompok kontrol. Edukasi merupakan suatu kegiatan memberikan informasi yang menguntungkan terhadap peningkatan pengetahuan (Auld \& Gambescia, 2011). Edukasi kesehatan menurut WHO (2015) adalah berbagai kombinasi pengalaman belajar 
yang dirancang untuk membantu individu dan komunitas memperbaiki kesehatan mereka, dengan meningkatkan pengetahuan atau sikap yang memengaruhi mereka. Menurut Maulana (2009); Sadiman, et al. (2009) media audiovisual dapat menyalurkan informasi ke otak lebih maksimal karena dapat memberikan gambaran nyata sehingga mudah untuk diingat.

Hasil uji statistik menunjukkan ada perbedaan yang bermakna antara pengetahuan sebelum dengan sesudah edukasi pada kelompok intervensi $(p=0,002)$ dan kelompok kontrol $(p=$ $0,018)$. Penelitian ini sesuai dengan penelitian Sulisnadewi, Nurhaeni, dan Gayatri (2012) yang menemukan bahwa skor pengetahuan, sikap, dan keterampilan masing-masing kelompok berbeda secara bermakna $(p<0,05)$ setelah diberikan edukasi dan ibu pada kelompok intervensi ditemukan berbeda secara bermakna dengan kelompok kontrol $(\mathrm{p}=0,000)$.

Sikap negatif mengalami penurunan baik pada kelompok intervensi maupun kontrol setelah dilakukan edukasi. Menurut Costa, Vasconcelos, dan Peres (2010) pembentukan sikap dipengaruhi beberapa faktor, yaitu faktor biologis yang mencakup usia dan status kesehatan, faktor psikologis, dan faktor komunikasi sosial. Faktor fisiologis seseorang akan menentukan bagaimana sikap seseorang dalam mengambil keputusan. Freldman-Stewart, et al. (2013) menemukan bahwa informasi yang lebih rinci dapat meningkatkan pengetahuan untuk mengambil keputusan. Ilvonen (2010) juga menjelaskan pengetahuan dan sikap merupakan bentuk interpretasi informasi dan pengalaman. Pembentukan sikap dapat dilakukan dengan cara kegiatan berulang, melalui kejadian yang menimbulkan kesan mendalam, dan pengalaman traumatik pada individu (Maulana, 2009).

Pengalaman dan informasi kemungkinan menjadi faktor yang mendukung perubahan sikap seseorang. Alhamda (2014) menyatakan sikap seseorang dapat berubah dengan diperolehnya tambahan informasi tentang objek tersebut melalui persuasi serta tekanan lingkungan dan budaya dari kelompok sosialnya. Merga dan Alemayehu (2015) menyebutkan berdasarkan analisis pernyataan terkait sikap, $146(62,9 \%)$ ibu dikategorikan memiliki sikap yang baik setelah diberi edukasi, meskipun dalam studi ditemukan bahwa ibu memiliki sikap/keyakinan yang berbeda-beda mengenai transmisi penyakit diare, metode pencegahan dan penanganan.

Hasil uji statistik menunjukkan ada perbedaan yang bermakna antara sikap sebelum dengan sesudah edukasi pada kelompok intervensi $(\mathrm{p}=$ 0,008); pada kelompok kontrol menunjukkan tidak ada perbedaan yang bermakna antara sikap sebelum dengan sesudah edukasi $(p=0,125)$. Sikap seseorang dapat berubah dengan diperolehnya tambahan informasi (Alhamda, 2014). Informasi yang berulang dan terus menerus diberikan secara bertahap akan diserap individu sebagai cara pembentukan sikap (Maulana, 2009). Proses edukasi merupakan upaya mengubah perilaku melalui pemberian informasi untuk mencapai kesehatan (Fenstein, et al., 2006). Penelitian ini sesuai dengan penelitian Merga dan Alemayehu (2015) yang menemukan bahwa pengetahuan dan sikap ibu dalam mengenali tanda dehidrasi akibat diare, pencegahan dan penanganan diare pada anak setelah edukasi secara bermakna dapat menurunkan risiko kejadian diare. Strategi informasi, edukasi, dan komunikasi dapat membantu meningkatkan pengetahuan dan menciptakan sikap positif di kalangan ibu tentang penyebab, pencegahan, dan manajemen diare.

Hasil penelitian menunjukkan ada perbedaan yang bermakna antara selisih skor pengetahuan kelompok intervensi dengan kelompok kontrol $(\mathrm{p}=0,008)$ dan selisih skor sikap antara kelompok intervensi dengan kelompok kontrol $(p=0,001)$. Penelitian ini sesuai dengan penelitian Sillah, Ho, dan Chao (2013) yang menemukan bahwa ibu yang terdidik dalam pengelolaan diare memiliki nilai pengetahuan dan sikap yang jauh lebih tinggi dibandingkan dengan mereka yang tidak terdidik. Ibu yang diberikan pendidikan pengelolaan diare memiliki nilai pengetahuan yang jauh lebih tinggi $(p=$ 
0,032) dan sikap $(\mathrm{p}=0,018)$ dibanding dengan mereka yang tidak diberikan pendidikan.

Penelitian Kapti (2010) juga menemukan bahwa sebagian besar ibu yang berpendidikan tinggi sebesar 58,3\% dan terbukti ada perbedaan pengetahuan dan sikap yang bermakna antara kelompok intervensi dan kontrol $(\mathrm{p}<$ 0,05). Pengetahuan dan sikap dipengaruhi oleh pendidikan seseorang, semakin tinggi pendidikan maka semakin banyak pengetahuan yang diperoleh seseorang (Surjadi, Torruellas, Ayala, Yee, \& Khalili, 2011). Orang dengan latar belakang pendidikan formal yang tinggi cenderung lebih aktif untuk mencari sendiri informasi yang dibutuhkan, namun demikian pengetahuan dan sikap seseorang dapat ditingkatkan dengan cara pemberian edukasi. Berdasarkan teori Health Promotion Model (Alligood, 2014) bahwa sosial kognitif dibentuk melalui observasi diri dan refleksi diri yang secara kuat dapat memengaruhi perilaku individu. $\mathrm{Pe}$ ngalaman dan faktor pribadi: biologi, psikologi, dan sosial budaya akan menentukan pengetahuan dan sikap spesifik sehingga tumbuh komitmen pada rencana tindakan yaitu perubahan perilaku (Alligood, 2014).

Hasil penelitian menunjukkan tidak ada perbedaan yang bermakna antara lama diare antara kelompok intervensi dengan kelompok kontrol $(p=0,796)$. Faktor yang memengaruhi lama diare antara lain usia, ASI eksklusif, frekuensi, dan keparahan diare (Strand, et al., 2012; Begum, 2014). Penelitian ini sesuai dengan penelitian Sillah, et al. (2013) yang menyatakan bahwa edukasi dapat meningkatkan nilai pengetahuan dan sikap, namun tidak memengaruhi praktik ibu dalam penanganan diare pada anak-anak. Sulisnadewi, et al. (2012) menemukan tingkat pengetahuan yang rendah akan menyebabkan ibu balita tidak dapat melakukan upaya pencegahan maupun perawatan pada anak diare. Perbedaan hasil antara pengetahuan, sikap, dan praktik dalam pengelolaan diare dapat disebabkan oleh fakta bahwa beberapa ibu tidak dapat menerapkan pengetahuan mereka tentang pengelolaan diare karena jad- wal yang sibuk dalam melakukan pekerjaan rumah tangga dan mengurus anak lain (Sillah, et al. 2013).

Webb, et al. (2010) mengungkapkan bahwa ibu memiliki pengetahuan yang baik dalam penanganan diare anak, namun tidak dalam praktiknya, terutama dalam penggunaan larutan rehidrasi oral. Masdiana (2016) menemukan perilaku ibu dalam perawatan/ pengobatan diare berupa mencari fasilitas kesehatan, pengobatan tradisional, merawat sendiri balita dengan diare di rumah, dan tidak melakukan apa-apa, sedangkan pencegahan diare yang dilakukan adalah menjaga makan dan minum anak, menjaga agar anak tidak terpapar dari anak lain yang sedang mengalami diare, menjaga kebersihan diri dan sanitasi lingkungan. Anak-anak dengan diare kebanyakan yang ditemukan dirawat di rumah perlu mendapatkan penanganan yang tepat, Oleh karena itu, perawat perlu memberikan pengetahuan dasar tentang praktik pengelolaan dan perawatan diare anak untuk mempersingkat durasi, mengurangi keparahan, dan mencegah terulangnya diare (Churgay \& Aftab, 2012). Menurut teori Health Promotion Model faktor penghambat perilaku spesifik pengetahuan dan sikap antara lain sifat serta pengalaman individu (Alligood, 2014). Faktor penghambat lain juga dikarenakan untuk mengubah perilaku dibutuhkan waktu antara 18224 hari (Lally, et al., 2009).

Pada pelaksanaannya, intervesi edukasi dalam penelitian ini tidak dilakukan dalam ruangan khusus, tetapi dilakukan di ruang tunggu dengan menggunakan earphone. Kondisi ini dapat menimbulkan distraksi pada responden. Keterampilan ibu merawat anaknya yang diare tidak dilakukan melalui observasi secara langsung sehingga terdapat kelemahan pada pengukuran variabelnya. Penelitian ini juga tidak mengukur faktor lain yang kemungkinan memengaruhi pengetahuan dan sikap ibu tentang penanganan diare dan lamanya diare selain edukasi.

Hasil penelitian ini memberikan dampak pada pelayanan khususnya di divisi promosi kese- 
hatan agar mengembangkan media edukasi yang lebih kreatif sesuai dengan dinamika masyarakat dewasa ini. Edukasi dengan media video dapat digunakan sebagai alat bantu petugas kesehatan dalam melaksanakan asuhan keperawatan karena dapat dilakukan mandiri dan kelompok. Edukasi tetap dapat dilakukan meskipun pelayanan kesehatan dalam kondisi keterbatasan sumber daya manusia.

\section{Kesimpulan}

Pengetahuan antara sebelum dan sesudah edukasi yang didapatkan pada kedua kelompok menunjukkan adanya perbedaan yang bermakna, dimana nilai statistik kelompok intervensi lebih kecil dari pada kontrol. Sikap antara sebelum dan sesudah edukasi yang didapatkan pada kelompok intervensi menunjukkan ada perbedaan yang bermakna sedangkan pada kelompok kontrol tidak ada perbedaan yang bermakna. Selisih skor pengetahuan dan sikap menunjukkan ada perbedaan, namun lama diare sesudah program edukasi menunjukkan tidak ada perbedaan bermakna antara kelompok intervensi dan kontrol.

Pihak institusi pelayanan kesehatan perlu mengembangkan berbagaai video edukasi perawatan diare yang dapat diakses dan memberikan kemudahan pelayanan kesehatan dalam memberikan asuhan keperawatan. Penelitian dinilai efektif dan efisien dari segi tenaga, waktu, dan biaya. Penelitian lain perlu dilanjutnya dengan tujuan mengembangkan bentuk edukasi video yang paling tepat dan sesuai untuk ibu dengan mempertimbangkan latar belakang pendidikan, budaya dan status sosial ekonomi (HM, NN, INR).

\section{Ucapan Terima kasih}

Penulis mengucapkan terima kasih kepada Kepala Puskesmas Kedaton Bandar Lampung dan Kepala Pos Kesehatan Kelurahan (PosKesKel) Wilayah Puskesmas Kedaton dan asisten peneliti yang ikut membantu jalannya penelitiaan, serta ibu-ibu yang bersedia menjadi responden.

\section{Referensi}

Alhamda, S. (2014). Buku ajar sosiologi kesehatan. Yogyakarta: Deepublish.

Alligood, M.R. (2014). Nursing theorists and their work (8th Ed.). St. Louis: Mosby Elsevier.

Auld, E., \& Gambescia, S. (2011). Health education. Oxford Bibliographies in Public Health. doi: 10.1093/obo/9780199756797-0044

Bastable, S.B. (2008). Nurse as educator: Principles of teaching and learning for nursing practice (3th Ed.). USA: Jones and Barlett Publishers, LLC.

Becker-dreps, S., Zambrana, L.E., Reyes, D., Vilchez, S., \& Weber, D.J. (2014). Household management of childhood diarrhea: A population-based study in Nicaragua. J Health Popul Nutr, 32 (1); 149-154. ISSN 1606-0997|\$ 5.00+0.20.

Begum, M. (2014). Breast feeding versus formula feeding and diarrheal diseases in infants and children: A review. Journal of Bangladesh College of Physicians \& Surgeons, 32 (1), 26-30. http://dx.doi.org/10.3329/jbcps.v32i 1. 21033

Caruso, B., Stephenson, R., \& Leon, J.S. (2010). Maternal behavior and experience, care access, and agency as determinants of child diarrhea in Bolivia. Revista Panamericana de Salud Pública, 28 (6), 429-439.

Churgay, C.A., \& Aftab, Z. (2012). Gastroenteritis in children: Part II. Prevention and management a handout on gastroenteritis treatment. American Family Physician, 85 (11). Retrieved from http://www.aafp.org /afp/2012/0601/p1066-s1.html

Clark, R.C. \& Mayer, R.E., (2016). E-learning and the science of instruction: proven guidelines for consumers and designers of multimedia 
learning (4th Ed.). Canada: John Wiley \& Sons Inc.

Costa, L.C.F., Vasconcelos, F.A.G., \& Peres, K.G. (2010). Influence of biological, social and psychological factors on abnormal eating attitudes among female university students in Brazil. Journal of Health, Population, and Nutrition, 28 (2), 173-181.

Dinas Kesehatan Provinsi Lampung. (2014). Profil kesehatan provinsi Lampung tahun 2014. Bandar Lampung: Dinas kesehatan provinsi Lampung.

Feinstein, L., Sabates, R., Anderson, T.M., Sorhaindo, A., \& Hammond, C. (2006). What are the effects of education on health? In Proceedings of the Copenhagen Symposium" Measuring the Effects of Education on Health and Civic Engagement.

Feldman-Stewart, D., O'Brien, M. A., Clayman, M. L., Davison, B. J., Jimbo, M., Labrecque, M., . . . Shepherd, H. (2013). Providing information about options in patient decision aids. BMC Medical Informatics and Decision Making, 13, S4. http://dx.doi.org/10.1186/ 1472-6947-13-S2-S4

Hockenberry, M.J., \& Wilson, D. (2013). Wong's essentials of pediatric nursing (9th Ed.). St. Louis, Missouri: Elsevier Mosby.

Ilvonen, I. (2010). Knowledge management and knowledge security-a conceptual comparison. Paper presented at the 352-X. Retrieved from http://search.proquest.com/docview/86 9507094? accountid=17242.

Kanungo, S., Mahapatra, T., Bhaduri, B., Mahapatra, S., Chakraborty, N. D., Manna, B., \& Sur, D. (2014). Diarrhoea-related knowledge and practice of physicians in urban slums of Kolkata, India. Epidemiology and Infection, 142 (2), 314-326. http://dx.doi. org/10.1017/S0950268813001076

Kapti, R. E. (2010). Efektifitas audiovisual sebagai media penyuluhan kesehatan terhadap peningkatan pengetahuan dan sikap ibu dalam tatalaksana balita dengan diare di dua Rumah Sakit Kota Malang (Tesis, tidak dipublikasikan). Program Studi Magister Ilmu Keperawatan Universitas Indonesia, Depok.

Kementerian Kesehatan Republik Indonesia. (2015). Buku bagan manajemen terpadu balita sakit. Jakarta: Kemenkes.

Kementerian Riset dan Teknologi Dikti. (2017). Smartphone Rakyat Indonesia. Diperoleh dari http://www.dikti.go.id/smartphone-rak yat-indonesia-2/

Lally, P., Van Jaarsveld, C.H., Potts, H.W., \& Wardle, J. (2010). How are habits formed: Modelling habit formation in the real world. European journal of social psychology, 40 (6), 998-1009.

Lamberti, L.M., Walker, C.L.F., Taneja, S., Mazumder, S., \& Black, R.E. (2015). The association between provider practice and knowledge of ORS and zinc supplementation for the treatment of childhood diarrhea in bihar, gujarat and uttar pradesh, India: A multi-site cross-sectional study. PLoS One, 10 (6). http://dx.doi.org/10.1371/journal.po ne. 0130845

Lin, W., Hang, C., Yang, H., \& Hung, M., B.S. (2011). 2005-2008 nutrition and health survey in Taiwan: The nutrition knowledge, attitude and behavior of 19-64 years old adults. Asia Pacific Journal of Clinical Nutrition, 20 (2), 309-318. Retrieved from https://search.proquest.com/docview/878058 686 ? accountid= 17242 .

Maulana, H.D.J. (2009). Promosi kesehatan. Jakarta: EGC

Masdiana, T.T. (2016). Persepsi, sikap, dan perilaku ibu dalam merawat balita dengan diare. Jurnal Ilmu Keperawatan, 4 (1), 100 112.

Merga, N., \& Alemayehu, T. (2015). Knowledge, perception, and management skills of mothers with under-five children about diarrhoeal disease in indigenous and resettlement communities in assosa district, western Ethiopia. Journal of Health, Population and Nutrition, 33 (1), 20-30. 
Nascimento, L.A., Joventino, E.S., de Oliveira Andrade, L.C., Gomes, A.L.A., \& Ximenes, L.B. (2014). Evaluation of educational videos produced in Brazil about infant diarrhea: a documental study. Online Brazilian Journal of Nursing, 13 (3), 311-320.

Sadiman, A.S., Rahardjo, R., Haryono, A., \& Rahardjito. (2009). Media pendidikan: pengertian, pengembangan, dan pemanfaatannya. Jakarta: PT Raja Grafindo Persada.

Sillah, F., Ho, H., \& Chao, J. C. -. (2013). The use of oral rehydration salt in managing children under 5 y old with diarrhea in the gambia: Knowledge, attitude, and practice. Nutrition, 29 (11), 1368-1373. http://dx.doi.org/10.10 16/j.nut.2013.05.014

Strand, T.A., Sharma, P.R., Gjessing, H., Ulak, M., Chandyo, R.K., Adhikari, R.K., \& Sommerfelt, H. (2012). Risk factors for extended duration of acute diarrhea in young children. PLoS One, 7 (5). http://dx.doi.org/ 10.1371/journal.pone.0036436.

Sulisnadewi, N.L.K., Nani, N., \& Dewi, G. (2012). Pendidikan kesehatan keluarga Efektif meningkatkan kemampuan ibu dalam merawat anak diare. Jurnal Keperawatan Indonesia; 15 (3), 165-170. doi: 10.7454/jki.v15i3.23.

Surjadi, M., Torruellas, C., Ayala, C., Yee, H.F., \& Khalili, M. (2011). Formal patient education improves patient knowledge of Hepatitis C in vulnerable populations. Digestive Diseases and Sciences, 56 (1), 213-219. http://doi. org/10.1007/s10620-010-1455-3

UNICEF (2015). Sekitar 35 juta balita masih beresiko jika target angka kematian anak tidak tercapai. Retrieved from http://www. unicef.org/indonesia/id/media_21393.html
Webb, A.L., Ramakrishnan, U., Stein, A.D., Sellen, D.W., Merchant, M., \& Martorell, R. (2010). Greater years of maternal schooling and higher scores on academic achievement tests are independently associated with improved management of child diarrhea by rural Guatemalan mothers. Maternal and child health journal, 14 (5), 799-806.

Word Health Organization. (2015). Global Health Observatory (GHO) data: Under-five mortality. Retrieved from http://www.who.int/gho/child_health/mortali ty/mortality_under_five/en/

World Health Organization. (2009). Diarrhoea: why children are still dying and what can be done. Geneva: WHO. Retrieved from http: //www.who.int/maternal_child_adolescent/d ocuments/9789241598415/en/

World Health Organization. (2013). WHO pocket book of hospital care for children: Guidelines for the management of common illness (2nd Ed.). Geneva: WHO.

Yalew, E. (2014). A qualitative study of community perceptions about childhood diarrhea and its management in Assosa District, West Ethiopia. BMC public health, 14 (1), 975.

Yilgwan, C.S. (2012). Prevalence of diarrhea disease and risk factors in Jos University Teaching Hospital, Nigeria. Annals of African Medicine, 11 (4), 217. doi: 10.4103/15963519.10285 . 